\title{
Engineering Design of A Gang Drilling Machine Equipped with Jig and Fixtures to Make A Prototype Machine in Birdcage Production
}

\author{
Eddy Widiyono, Winarto, Rivai Wardhani, and Liza Rusdiyana ${ }^{1}$
}

\begin{abstract}
This paper is dealing with the engineering design of a gang drilling machine with jig \& fixtures to make a prototype machine. This effort has been done in order to solve the problem which aroused in small business enterprises producing birdcages. The problem was how to minimize the production time in making a lot of holes that have same distance and straightness. Hopefully, the prototype machine can help the small business enterprises to increase their production rate.The design engineering process has been carried out by variant approximation on dowel pin modular fixtures in order to simplify fixtures design. CAD CAM software has also been used as fixtures synthesized method including geometric analysis and three dimensional fixtures assembling. The resulting prototype machine can be well operated and based on the running test, it can be concluded that the greater the motor rotation the greater the power needed. As for teak wood, at $250 \mathrm{rpm}$ motor rotation the power needed is 26.5 watt, and at $400 \mathrm{rpm}$ the motor needs power of 43.6 watt while at $600 \mathrm{rpm}$ the motor needs power of 600 watt. The power consumption is also depends on the type of material, the better the mechanical properties of the materials, the higher the power consumption. For cast iron, the 400 rpm motor rotation needs power as high as $\mathbf{5 6 9 . 7}$ watt. This prototype of gang drilling machine needs power of $\mathbf{3 5 0}$ watt to make five holes on teak wood while ordinary drilling machine needs total power of 1350 watt.
\end{abstract}

Keywords — birdcage, fixtures, gang drill, jig, small business

\begin{abstract}
Abstrak-Makalah ini membahas mengenai rekayasa prototipe gang drill dengan jig \& fixturenya, untuk mengatasi salah satu permasalahan yang ada di UKM sangkar burung, di dalam proses pembuatan sangkar burung, perlu adanya penerapan teknologi tepat guna yang berupa satu unit mesin gang drill dengan jig \& fixturenya yang mampu membuat lubang yang banyak, dengan jarak dan kelurusan yang sama secara cepat, sehingga produksi UKM sangkar burung dapat ditingkatkan. Pengembangan metode perancangan dan modifikasi fixture dengan pendekatan varian pada modular fixture berbasis dowel pin juga bisa memudahkan dalam perancangan fixture. Sofware CAD CAM dapat digunakan sebagai metode sintesis fixture termasuk analisis geometri, perencanaan dan perakitan fixture secara 3 dimensi dengan cepat. Mesin gang drill dengan jig \& fixture, hasil rekayasa dapat bekerja dengan baik dan berdasarkan hasil pengujian makin tinggi putaran motor, maka makin besar daya yang dibutuhkan, untuk bahan kayu jati pada putaran 250 rpm, daya yang dibutuhkan sebesar 26,5 W dan pada putaran 600 rpm daya yang dibutuhkan $600 \mathrm{~W}$. Juga kebutuhan daya pada proses drilling, juga tergantung jenis bahan yang akan diporoses, makin tinggi harga sifat mekanik bahan, maka kebutuhan daya untuk proses drilling makin besar. Kebutuhan daya untuk proses drilling pada bahan kayu jati dengan putaran motor 400 rpm sebesar 43,6 W, sedangkan untuk bahan besi tuang dengan putaran motor $400 \mathrm{rpm}$ sebesar 569,7 W. Kebutuhan waktu dan daya dalam pembuatan 5 lubang dengan bahan kayu jati menggunakan mesin gang drill 1 motor 5 pahat jauh lebih rendah, bila dibanding dengan drill 1 motor 1 pahat sebesar $350 \mathrm{~W}$ dan $1350 \mathrm{~W}$. Hal ini mesin gang drill 1 motor 5 pahat menjadikan produktivitas UKM produk sangkar burung akan meningkat.
\end{abstract}

Kata Kunci-sangkar burung, fixture, gang drill, jig, industri kecil

\section{INTRODUCTION}

$\mathrm{T}$ he management of fixtures system in machining remain relatively stagnant especially the progress of technology development. This condition governs to the needs of scientifically-based management of model formalization which can give significant contribution to the development of fixture systems [1].

The development of design method and fixtures modification using variant approximation based on dowel pin modular fixtures can also make fixtures design easier [2].

Eddy Widiyono, Winarto, Rivai Wardhani, Liza Rusdiyana are with Department of Mechanical Engineering D.3 Program, Faculty of Industrial Technology, Institut Teknologi Sepuluh Nopember, Surabaya, 60111, Indonesia. Email: eddy_w@me.its.ac.id, winarto@me.its.ac.id, rivaiw@me.its.ac.id, liza@me.its.ac.id.
CAD/CAM/CAE/CAT softwares can be used as fixture synthesized method including geometric analysis, design and assembling of fixture in three dimensional mode [34].

Expert system has been developed for designing the fixtures which can be used as a basic guide in designing and assembling the appropriate fixtures [5].

When assembling fixture in a machining process, the workpiece position, tool movement, pin/locator flexibility have to be considered so that the elements of jig and fixture will be interchangeable and reusable [6].

Designing and assembling of jig and fixture can be carried out using finite element method, then simulated by the ANSYS software [7]. Carbon fiber composite has been used as the material of jig and fixture in car assembling [8].

This paper deal with the engineering design of a gang drill prototype in order to help some small enterprises 
that produce birdcage to solve their problem. Their problem was how to drill many holes in one step, how to maintain the same distance between holes, and how to maintain the holes straightness. In the past, the drilling process was done one by one for each hole so that the drilling process was very exhausted [9].

This gang drillig machine is equipped with jig and fixtures specially in the type of drilling jig, which control the relationship between work piece and cutting tool. Meanwhile, the fixtures in this machine is used as the clamping elements for gripping the work piece.

To realize this engineering process, it would require the calculation of the main components such as shaft, gear, bearing and spring and pin.

The following equation is used for the shaft calculation [10-12]:

$D \geq \sqrt[6]{\frac{16^{2} M b^{2}+16^{2} M t^{2}}{\pi^{2}\left(\frac{K s . S y p}{N}\right)^{2}}}$

After obtaining the shaft diameters and materials used, so one can determine the shaft to get the long life usage.

Gears are used to transmits power and rotational motion between two shafts arranged parallel. The type of the gear used in this design is the straight spur gears, which has the in the following equations to used in the engineering process $[1,12]$.

To obtain the rotation of the gear $\left(n_{2}\right)$,

$\frac{n_{2}}{n_{1}}=\frac{d_{1}}{d_{2}}$

The number of teeth $\left(N_{t}\right)$ can be calculated as follows,

$P=\frac{N t}{d}$

When two gears are in mesh, the distance between the center of the two gears $\left(C_{1}\right)$, is equal to one half the sum of their pich diameters. In equation form [11],

$C_{1}=\frac{d_{1}+d_{2}}{2}$

In Figure 1, the center distance $\left(C_{1}\right)$, is shown. And the ratio $r_{v}$ between gears

$r_{v}=\frac{n_{2}}{n_{1}}=\frac{N t_{1}}{N t_{2}}=\frac{d_{1}}{d_{2}}$

The equations bellow is used to find the torque $(T)$ and the tangential force $\left(F_{t}\right)$,

$$
\begin{gathered}
T=\frac{H p .63000}{n} \\
F t=\frac{T}{d / 2}
\end{gathered}
$$

Before getting a dynamic load, it is necessary to get the peripheral speed $(v p)$,

$v p=\frac{\pi d n}{60}$

The dynamic effect on gear teeth, due to such factors as inaccurately cut teeth, improper tooth spacing, improper mounting, deflection due to elasticity of the gears and shaft, and irregular load requirements must be taken in account in this preliminary design stage. The dynamic load $(F d)$ can be calculated by,

$F d=\frac{600+v p}{600} F t$ for $0 \leq \mathrm{vp} \leq 2000 \mathrm{ft} / \mathrm{min}$

So that the width of the teeth $(b)$ of gears can be obtained by the following equation,

$b=\frac{F d}{d \cdot Q \cdot k}$

$Q=\frac{2 \cdot N t_{1} \cdot N t_{2}}{N t_{1}+N t_{2}}$

In order to prevent the gear damage, hence one shall have to know the size of the working load, that is :

$F b=\frac{S \cdot b \cdot Y}{P}$

$\sigma_{t}=\frac{F_{t} \cdot K_{o} \cdot p \cdot K_{s} \cdot K_{m}}{K_{v} \cdot b \cdot J}$

and,

$S_{a d}=\frac{S_{a t} \cdot K_{L}}{K_{T} \cdot K_{R}}$

Bearings should have also been chosen appropriately by determining the working load and life of the bearings $[10,13]$.

$F t=\sqrt{{F_{B H}{ }^{2}+F_{B V}^{2}}^{2}}$

$P=V . F t$

Bearings lifetime,

$L_{10 \mathrm{~h}}=\left(\frac{C_{2}}{P_{1}}\right)^{b} \times \frac{10^{6}}{60 . n}$

Pins have also need to be taken into account, so that damage can be prevented. In the design of the pin, the effect of the shear and the compressive stress needs to be considered [13].

Review to the shear stress

$\frac{K_{s} \cdot S y p}{N} \geq \frac{2 T}{D \cdot W \cdot L_{\text {min }}}$

Review to the compressive stress,

$\frac{K_{c} \cdot S y p}{N} \geq \frac{4 T}{D \cdot H \cdot L}$

(19)

Spring is an important component, with the primary function of a spring is to absorb shock and to support the weight of the machine. To determine the dimensions of the corresponding spring, the spring correction factors diagram in Figure 2 can be used.

Spring ratio $\left(\mathrm{C}_{3}\right)$,

$C_{3}=\frac{D}{d}$

$K_{w}=\frac{4 C_{3}-1}{4 C_{3}-4}+\frac{0,615}{C_{3}}$

Planned maximum deflection of the spring by 4.6 ins, so that deflection clash allowance $\mathrm{Y}_{\text {clash }}$ is $10 \%$ of the $\mathrm{Y}_{\text {op-max }}$

$Y_{\text {clash }}=10 \% \times Y_{0-\max }$

Length of solid spring $\mathrm{L}_{\mathrm{s}}$,

$L_{s}=L_{f}-\left(Y_{1}+Y_{o p-\max }+Y_{\text {clash }}\right)$ 
The number of coil springs (Nt),

$N t=\frac{L_{s}}{d}$

Because the springs are squared and ground end, the winding number is two not active. So the number of active coils $(\mathrm{Na})$ is,

$\mathrm{Na}=\mathrm{Nt}-2$

Since the spring is experiencing the beginning deflection, then spring is in static conditions has received a static force. If the specified used shear modulus $\mathrm{G}=$ $11.5 \times 10^{6}$, then the static force that resulted in large initial deflection to:

$P_{\text {min }}=P_{\text {tatis }}=\frac{11.5 \times 10^{6} \mathrm{xd}^{4} \mathrm{xy}_{1}}{64 \mathrm{xN}_{\mathrm{a}} \mathrm{xR}^{3}}$

Furthermore, from load fluctuations can be determined the average load $\left(\mathrm{P}_{\text {mean }}=\mathrm{P}_{m}\right)$ and load amplitude $\left(\mathrm{P}_{\text {range }}=\right.$ $\mathrm{P}_{r}$ ) as follows,

$P_{m}=\frac{P_{\max }+P_{\min }}{2}$

$P_{r}=\frac{P_{\max }-P_{\min }}{2}$

From both value to get comparison between $P_{r}$ and $P_{m}$ as follows:

$\frac{\mathrm{P}_{\mathrm{r}}}{\mathrm{P}_{\mathrm{m}}}=\frac{1}{1.25}=\frac{\tau_{\mathrm{r}}}{\tau_{\mathrm{m}}}$

Average shear stress $\left(\tau_{a}\right)$ that occurs at,

$\tau_{m}=K_{w} \frac{16 \cdot P_{m} \cdot R}{\pi \cdot d^{3}}$

The shear stress amplitude $\left(\tau_{a}\right)$ is known from the comparison between the average shear stress and amplitude. Shear stress amplitude value,

$\tau_{\mathrm{a}}=\frac{\tau_{\mathrm{m}}}{1.25}$

\section{METHOD}

Prototype of gang drilling machine is equipped with Jig \& Fixture, is an engineered effort to increase production of the bird cage small business (see Figure 3).

\section{A. Materials Test}

Materials used in this study, in determining the speed of drilling and power requirements are teak, aluminum, brass and cast iron that have mechanical properties, such as Table 1 .

\section{B. Research Flowchart}

In order to design the prototype of gang drill equipped with jig \& fixture, it is recessary to have some steps as, shown in the flow chart in Figure 4.

\section{Examination}

In order to get a gang drill machine which is able to work properly, the testing by variying the material and rotational speed are conducted. Therefore, the power requirements for fine drilling chisels work simultaneously are known. Five rotational speed (150 $\mathrm{rpm}, 250 \mathrm{rpm}, 400 \mathrm{rpm}$ and $1450 \mathrm{rpm}$ ) are used in the experiments while the tested materials are teak wood, aluminum, brass and cast iron. Every drilling process for certain material and rotational speed is carried out with 5 (five) times iteration.

To find out, how much gang drilling machine can be useful for small business in order to improving productivity, verification of drilling speed and power requirements are performed for single chisel drilling machine with a single motor gang drill. Therefore, time difference and resources required in the drilling process between them can be known. Tests is carried out by varying the number of chisell drill (1 pieces, 2 pieces, 3 pieces, 4 pieces and 5 pieces) and materials (teak wood, aluminum, brass and cast iron). Each test is iterated five time.

\section{RESULTS AND DISCUSSION}

Based on the calculations, the countershaft and the driven shaft have the dimension, which are listed in Figure 5 and 6, respectively. Where as the specifications are given in Table 2 .

Futhermore, the straight gears are used to transmit power and rotary motion between the two shaft which are arranged parallely as shown in Figure 7 and 8 . The specification of the gears are given in Table 3.

As for bearings, roller bearings (ball bearings, single row- deep groove) are chosen with the specification in Table 4. The Pin and spring are specified in Table 5 and 6 respectifely.

Based on the results of testing by varying the rotational speed and test materials, the power requirements for 5 (five) drilling chisels that work in conjunction, can be seen in Table 7.

It can be observed from Figure 9 that the power consumption is needed for the higher rotation. As for teak wood, the rotation of $250 \mathrm{rpm}$ and $600 \mathrm{rpm}$ consume the power of $26.5 \mathrm{~W}$ and $600 \mathrm{~W}$, respectively. Motor rotation speed has significant effect to cutting speed, force and torque. The greater the motor rotation, the higher the cutting speed. How ever, the power demand also increase of force and torque.

By observing Figure 9, it can be known that there are some differences on the power requirements for different materials. Cast iron consumens the higher while teak wood pays the lower one for the some motor rotation due to the different of mechanical properties.

The differences between the two drill machines lies on the construction design. The first type is the gang drill machine with one motor and five chisel. A single main shaft with four driven-shaft and four link-gear are used as the power transmission system. On the other hand, the scond type, ehich is the original machine used by small business, uses a motor with single chisel and the drivenshaft only.

Figure 10 reveals as the power requirement for manufacturing five holes on the different material using the two type gang drill machines (see Figure 11), while Figure 12 inform the time needed to finish that tasks. When five chisel work simultantly using gang drill machine, both time and power requirement are reduced compare to drilling process using single chisel. 
Therefore, gang drill machine has increased productivity and efficience of birdcage manufacturer.

\section{CONCLUSION}

1. Prototype of gang drill equipped with a jig \& fixture, has been made and tested. Testing should that the machine can be functionalized properly.

2. The higher the motor rotation, the greater of power needed. For teak wood at $250 \mathrm{rpm}$ requires power of $26.5 \mathrm{~W}$. At the higher rotaton of $600 \mathrm{rpm}$, the greather power of $600 \mathrm{~W}$ consumed.

3. Power requirements of the drilling process, depends on the mechinal properties of materials. Materials with higher mechanical properties consume more power in order to accomplish the process than lower ones. For rotation at $400 \mathrm{rpm}$, teak wood need power of 43.6 W only while cast iron spending power of $569.7 \mathrm{~W}$

4. Power requirements to make 5 holes for teak wood using gang drill machine with 1 motor and 5 chisels is lower than the ordinary/original machine 1 motor and 1 chisel.

5. The drilling time to make 5 holes using gang drill machine is shorter than the ordinary machine.

\section{ACKNOWLEDGEMENT}

Directorate General of Higher Education, Ministry of National Education.

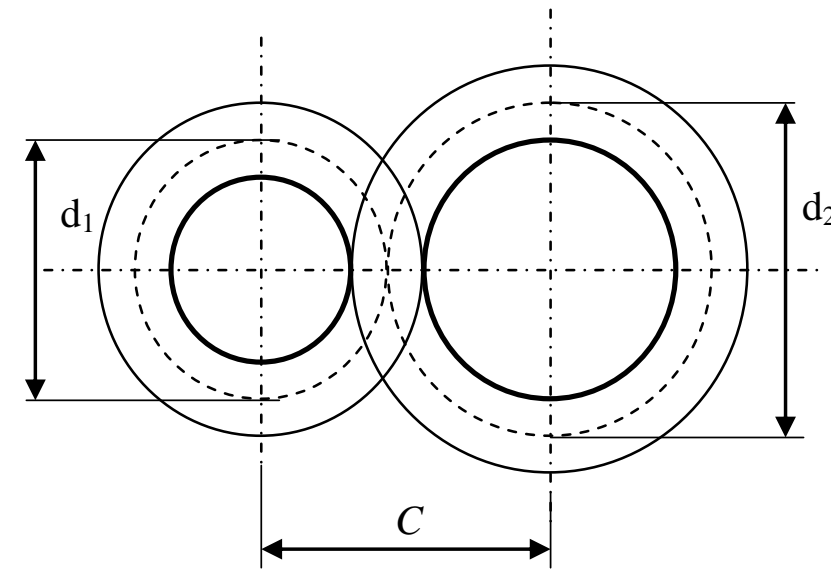

Figure 1. The center distance $\left(C_{1}\right)$

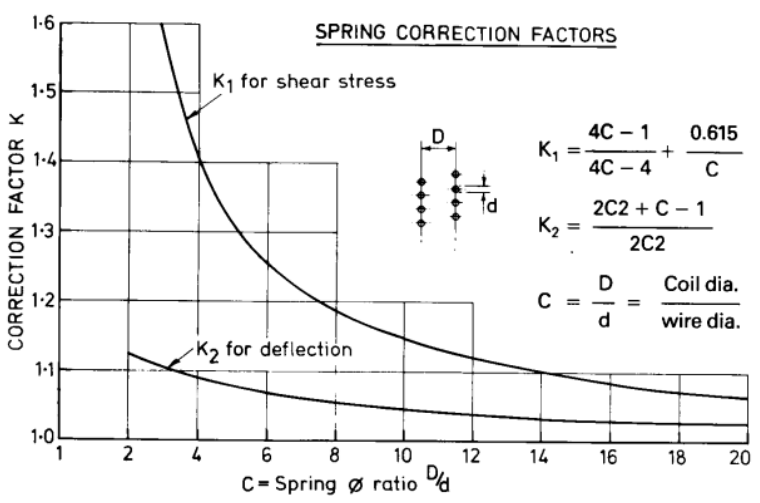

Figure 2. The spring correction factors diagram [14]
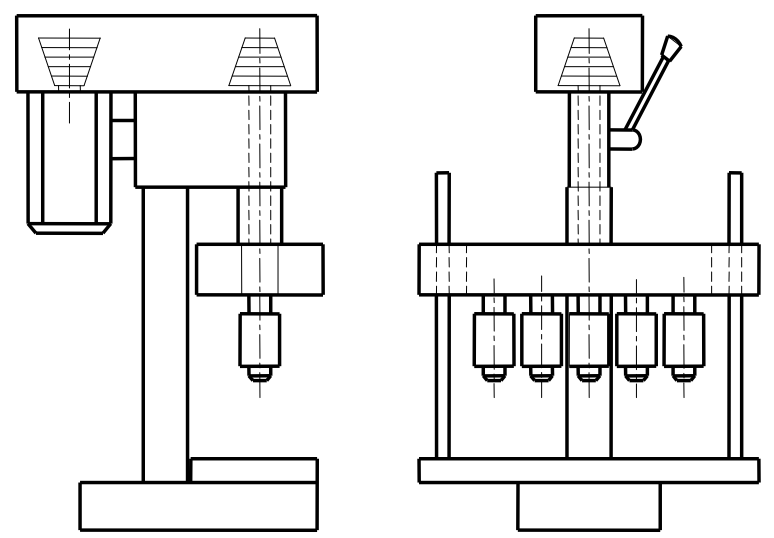

Figure 3. Prototype of gang drilling machine is equipped with jig and fixture 


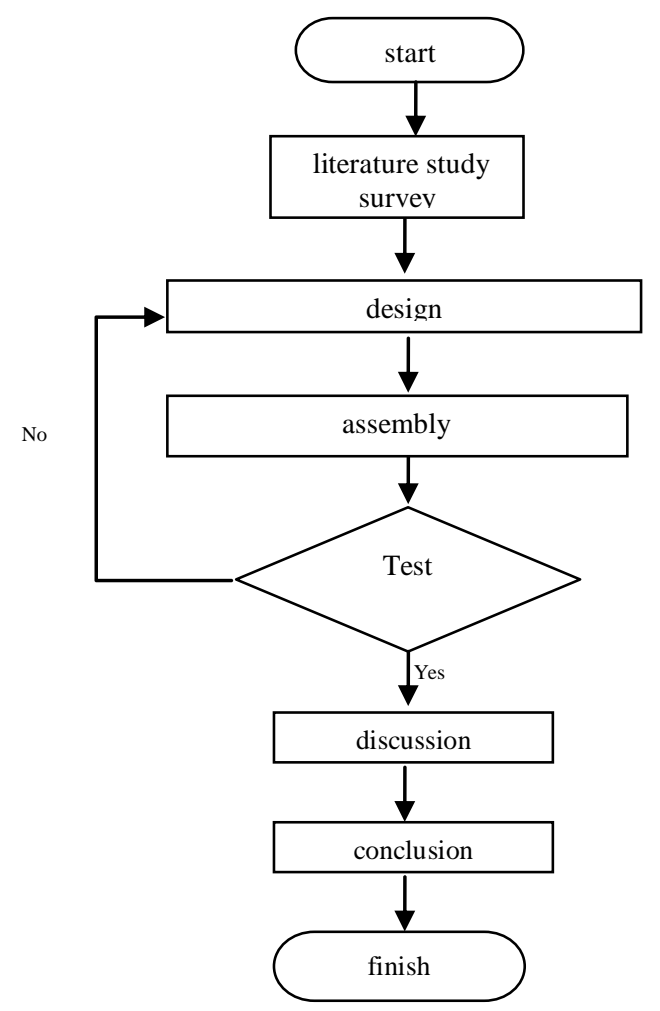

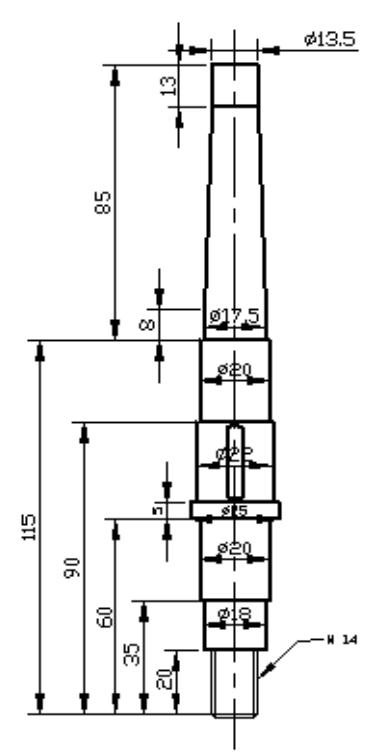

Figure 5. Countershaft
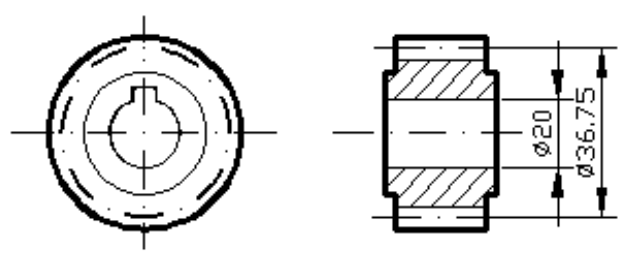

Figure 7. Pinion

Figure 4. Research methodology flowchart

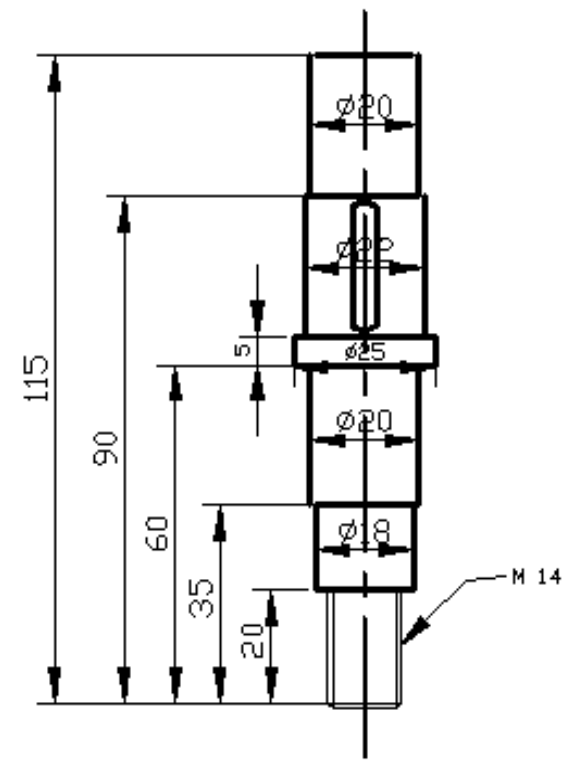

Figure 6. Driven shaft

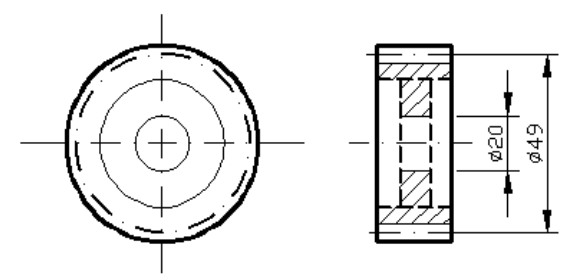

Figure 8. Gear 


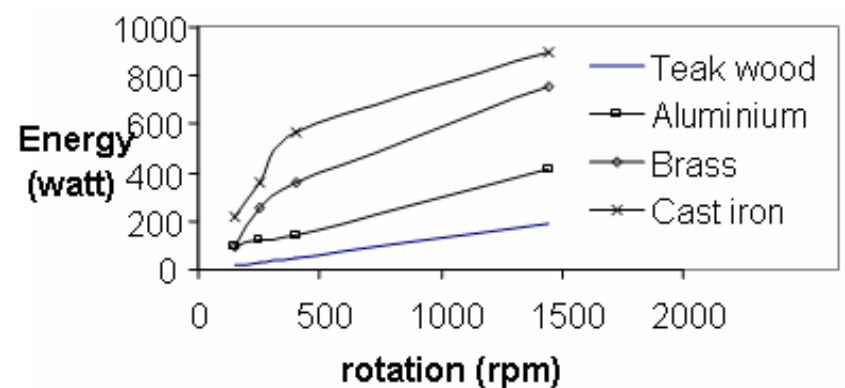

Figure 9. Diagram of energy requirement of gang drilling machine with materials and rotation variation

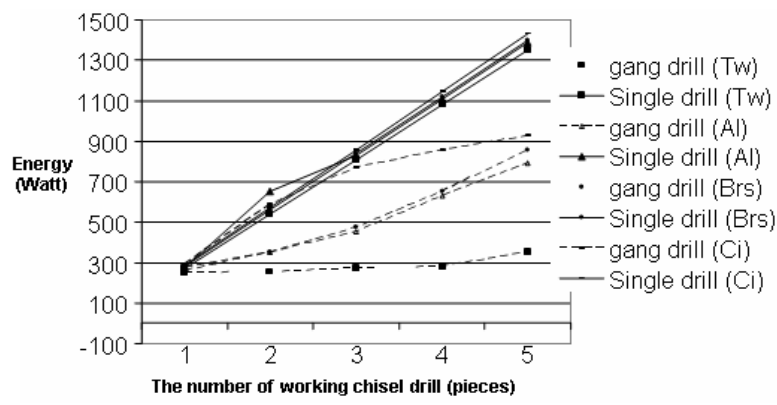

Figure 10. Diagram of comparison energy requirement of gangway machine drill with one motor and machine drill with one chisel (single drill)

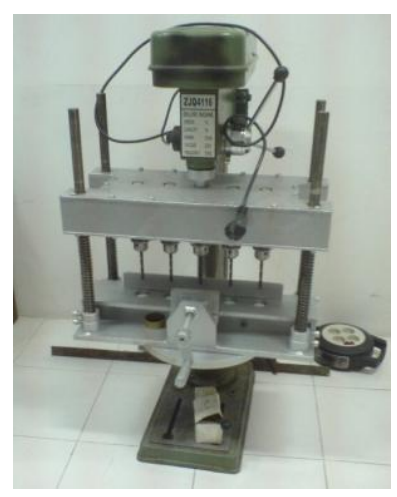

Figure 11. Gang Drilling Machine [9]

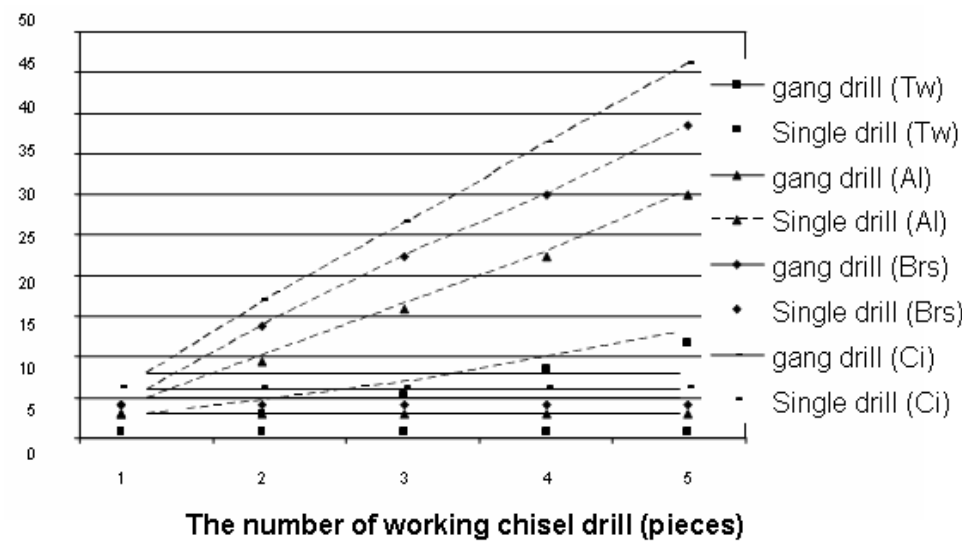

Figure 12. Diagram of comparative length of time drilling, drill machine with a gang drill machine with one motor and one chisel (single drill)

TABLE 1

MechaniCAL PRoPerties of MATERIAL TeSt

\begin{tabular}{lccc}
\hline \multirow{2}{*}{ Material Test } & \multicolumn{2}{c}{ Tensile Stress } & Elongation \\
\cline { 2 - 4 } & Tensile MPa & Yield Mpa & $\%$ \\
\hline Teak & 50 & 40 & $0 \%$ \\
Aluminium & 70 & 20 & $60 \%$ \\
Brass & 200 & 70 & $4 \%$ \\
Cast Iron & 380 & 120 & $1 \%$ \\
\hline
\end{tabular}

TABLE 2.

SHAFT SPECIFICATION

\begin{tabular}{lcc} 
& \multicolumn{3}{c}{ SHAFT SPECIFICATION } \\
\hline \multirow{3}{*}{ Material } & Counter shaft & Shaft driven \\
\cline { 2 - 3 } & Carbon Steel AISI & Carbon Steel AISI \\
& 1137 & 1137 \\
\hline
\end{tabular}


TABLE 3 .

SPECIFICATION OF GEARS

\begin{tabular}{ccc}
\hline & Pinion & Gear \\
\hline Material & gear steel & gear steel number 325 \\
& number 350 & $49 \mathrm{~mm}$ \\
Diameter & $36.75 \mathrm{~mm}$ & 28 pieces \\
Number of & 21 pieces & \\
teeth & & $21 \mathrm{~mm}$ \\
Width of teeth & $24 \mathrm{~mm}$ &
\end{tabular}

TABLE 5 .

PIN SPECIFICATION

\begin{tabular}{|c|c|}
\hline $\begin{array}{l}\text { Type of pin } \\
\text { Material }\end{array}$ & $\begin{array}{c}\text { Square standart key } \\
\text { malleable iron grade } 32510\end{array}$ \\
\hline Length & 0.8 in \\
\hline Width (W) & 0.25 in \\
\hline High & 0.25 in \\
\hline
\end{tabular}

TABLE 4.

BEARING SPECIFICATION

\begin{tabular}{cc}
\hline Type of bearing & Type of roller \\
\hline Inside diameter (d) & $20 \mathrm{~mm}$ \\
Outside diameter (D) & $47 \mathrm{~mm}$ \\
Width & $12 \mathrm{~mm}$ \\
Co & $715 \mathrm{lb}$ \\
C & $1710 \mathrm{lb}$ \\
\hline
\end{tabular}

TABLE 6.

SRING SPESIFICATION

\begin{tabular}{cc}
\hline Spring material & ASTM class 20 \\
\hline Spring free length (Lf) & Malleable iron grade \\
& 32510 \\
Inner diameter spring (D) & 0.25 in \\
Outer diameter spring (Do) & 0.25 in \\
Wire diameter (d) & 0.8 in \\
\hline
\end{tabular}

TABLE 7.

ENERGY REQUIREMENT OF GANG DRILLING MACHINE WITH MATERIALS AND ROTATION VARIATION

\begin{tabular}{ccccc}
\hline Rotation & Teak wood (Tw) & Aluminium $(\mathrm{Al})$ & Brass $(\mathrm{Brs})$ & Cast iron $(\mathrm{Ci})$ \\
\hline 150 & 15.6 & 90.8 & 95.1 & 212.8 \\
250 & 26.5 & 122.0 & 259.0 & 355.2 \\
400 & 43.6 & 144.4 & 355.7 & 569.7 \\
1450 & 190.1 & 417.9 & 758.8 & 896.9 \\
\hline
\end{tabular}

\section{REFERENCES}

[1] L. A. Consalter and Boehs, "An Approach to Fixture Systems Management in Machining Processes," Journal of the Braz. Soc. Of Mech. Sci. \& Eng. vol.XXVI, no.2, p. 145-152, 2004.

[2] T. M. Nugroho and A. Ma'ruf, "Pengembangan Metode Perancangan dan Modifikasi Fixture dengan Pendekatan Varian Pada Modular Fixture Berbasis Dowel-Pin," Jurnal Teknik Gelagar, vol.19, no.01. pp.59-65, 2008.

[3] D. T. Pham, S. Z Su., M. Z. Li., and C. G. Liu, Digital Dieless Tooling Technology for Manufacturing 3D Panel Using MultiPoint Forming Methodology, Manufacturing Engineering Centre, Cardiff, CF 24 3AA, UK, 2008.

[4] P. Qingjin and K. Xiumei, Fixture Feasility: Methods and Techniques for Fixture Planning, Computer-Aided Desain \& Applications, vol.5, no.1-4, pp. 423-433, 2008

[5] D. Vukelic and J. Hodolic, "Machining Fixture Design Via Expert System," Adeko, Machine Design Journals, ISSN 1821-1259, 2009.

[6] M. Krsulja, B .Barisic, and J. Kudlacek, Assembly Setup For Modular Fixture Machining Process, Advanced Engineering 3, ISSN 1846-5900, 2009.
[7] S. Siwadamrongpong and U. Ongarjwutichai, "Simulation and Design of Jig for Bus's Chassis Production," International Journal of Mechanics, vol.4, issue 4, pp. 87-93, 2010.

[8] E. Leondardt, J. Waltman, and V. Iyer, "Composite Hood Jig for Automotive Assembly Process", in Proceeding of the IJMEINTERTECH Conference, Session IT 301-042, 2006.

[9] Winarto and E. Widiyono, "Penerapan Teknologi Tepat Guna, Prototype Mesin Gang Drill Dengan Jig \& Fixture, Dalam Peningkatan Produksi Dan Kualitas Industri Kecil Sangkar Burung, Guna Memenuhi Pangsa Pasar Luar Jawa," Laporan Program Voucher Dikti 06/07, 2007.

[10] J. A. Collins, Mechanical Design of Machine Elements and Machines, Jon Wiley and Sons Inc., New York, 2003.

[11] D. Aaron, D. Walter, J. Michels, and E.W. Charles. Machine Design Theory and Practice, Macmillan Publishing Co, Inc, New York, 1975

[12] R. C. Hibbeler, Engineering Mechanics: Dynamics : Upper Saddle River, Prentice-Hall, 2001

[13] D. B. Margitu, Mechanical Engineer's Handbook, Academic Press, San Diego, 2001.

[14] T. Cain, Spring Design and Manufactur, Argus Book Limited, England, 1988. 